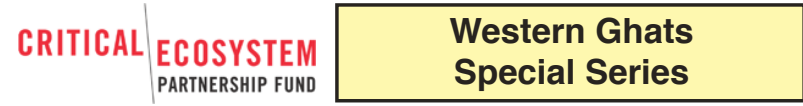

\title{
DISTRIBUTION, THREATS AND CONSERVATION STATUS OF HYPSELOBARBUS THOMASSI (DAY, 1874), A POORLY KNOWN CYPRINID FISH OF THE WESTERN GHATS FRESHWATER ECOREGION
}

ISSN

Online 0974-7907 Print 0974-7893

OPEN ACCESS

\author{
Anvar Ali ${ }^{1}$, Siby Philip ${ }^{2}$, Neelesh Dahanukar ${ }^{3}$, C.R. Renjithkumar ${ }^{4}$, A. Bijukumar ${ }^{5}$ \& \\ Rajeev Raghavan ${ }^{6}$ \\ 1,2,6 Conservation Research Group (CRG), St. Albert's College, Kochi, Kerala 682018, India \\ ${ }^{2}$ Department of Zoology, Nirmalagiri College, Koothuparambu, Kannur, Kerala 670701, India \\ ${ }^{3}$ Indian Institute of Science Education and Research (IISER), Dr. Homi Bhabha Road, Pashan, Pune, Maharashtra \\ 411008, India \\ ${ }^{4}$ School of Industrial Fisheries (SIF), Cochin University of Science \& Technology (CUSAT), Kochi, Kerala 682016, India \\ ${ }^{5}$ Department of Aquatic Biology \& Fisheries, University of Kerala, Trivandrum, Kerala 695581, India \\ ${ }^{3,6}$ Systematics, Ecology \& Conservation Laboratory, Zoo Outreach Organization (ZOO), 96 Kumudham Nagar, \\ Vilankurichi Road, Coimbatore, Tamil Nadu 641035, India \\ ${ }^{1}$ anvaraliif@gmail.com, ${ }^{2}$ siby@conservationresearchgroup.com, ${ }^{3}$ n.dahanukar@iiserpune.ac.in, \\ ${ }^{4}$ renjith.kumar347@gmail.com, ${ }^{5}$ abiju@rediffmail.com, ${ }^{6}$ rajeevraq@hotmail.com (corresponding author)
}

\begin{abstract}
The Red Canarese Barb, Hypselobarbus thomassi (Day, 1874) is an endemic cyprinid fish of the rivers of the Western Ghats of India, which has been listed as 'Critically Endangered' in the IUCN Red List of Threatened Species. Like many of its congeners, $H$. thomassi is poorly known with very few verified records and voucher specimens in the past decades. Based on fresh materials collected from three west flowing rivers of Kerala, we provide information on its identity, distribution, phylogenetic position, threats and conservation. An updated conservation assessment of this species following the IUCN Red List criteria is also provided.
\end{abstract}

Keywords: Barb, freshwater fish, Gonoproktopterus, India, IUCN Red List.

DOI: http://dx.doi.org/10.11609/JoTT.o3838.5202-13 | ZooBank: urn:Isid:zoobank.org:pub:4AC19BCE-A83C-495E-819B-76D89EF5DDE9

Editor: Topiltzin Contreras MacBeath, Universidad Autónoma del estado de Morelos, México.

Date of publication: 26 December 2013 (online \& print) Manuscript details: Ms \# 03838 | Received 02 November 2013 | Final received 17 December 2013 | Finally accepted 18 December 2013

Citation: Ali, A., S. Philip, N. Dahanukar, C.R. Renjithkumar, A. Bijukumar \& R. Raghavan (2013). Distribution, threats and conservation status of Hypselobarbus thomassi (Day, 1874), a poorly known cyprinid fish of the Western Ghats freshwater ecoregion. Journal of Threatened Taxa 5(17): 5202-5213; http://dx.doi. org/10.11609/JoTT.03838.5202-13

Copyright: (C) Ali et al. 2013. Creative Commons Attribution 3.0 Unported License. JoTT allows unrestricted use of this article in any medium, reproduction and distribution by providing adequate credit to the authors and the source of publication.

Funding: Rajeev Raghavan thanks the Mohammed Bin Zayed Species Conservation Fund (MBZSCF; Project 1225670) and the North of England Zoological Society (NEZS), Chester Zoo for funding the project on 'Lost fishes of the Western Ghats'. Neelesh Dahanukar is supported by the Inspire Faculty Fellowship of the Department of Science and Technology (DST), Government of India.

Competing Interest: The authors declare no competing interests. Funders had no role in study design, collection, analysis and interpretation of data and manuscript writing.

Author Contribution: AA, SP, CRR, AB \& RR carried out the field work and collected the specimens; RR studied museum specimens; AA performed morphometry, ND carried out the extraction of DNA and related molecular laboratory work; SP carried out the phylogenetic analysis; AA, SP, ND, AB \& RR wrote the manuscript.

Author Details, Acknowledgements: see end of this article.
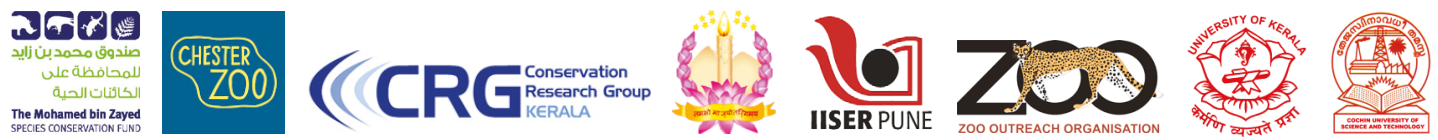

The publication of this article is supported by the Critical Ecosystem Partnership Fund (CEPF), a joint initiative of l'Agence Française de Développement, Conservation International, the European Commission, the Global Environment Facility, the Government of Japan, the MacArthur Foundation and the World Bank. 


\section{INTRODUCTION}

Hypselobarbus thomassi (Day, 1874) (Images 1 \& 2 ) is a poorly known large cyprinid species endemic to the Western Ghats freshwater ecoregion in peninsular India (Devi \& Ali 2011). Day (1874, p707) described Barbus (= Hypselobarbus) thomassi from South Canara as a large barb growing to more than $450 \mathrm{~mm}$ in length. Subsequently, Day (1878, p 567; 1889, p 311) provided additional notes on this species. Historic literature (Day 1874, 1879, 1889) suggested that this species is restricted in distribution to the inland waters of the erstwhile South Canara, i.e., the area encompassing current day Dakshin Kannada District of Karnataka, and Kasargod District of Kerala.

Like many other species within this genus, $H$. thomassi has also been poorly represented in collections, and not many records are available in the primary literature. The first record of $H$. thomassi outside its type locality was most likely made by Jayaram et al. (1976) from the rivers of the Cardamom Hills, as previous ichthyological surveys in Travancore (e.g., Pillai 1929; John 1936) and the Anamalai Hills (Silas 1951) had not mentioned this species. Subsequent compilations and checklists (for e.g., Talwar \& Jhingran 1991; Menon 1999; Easa \& Shaji 2003; Devi et al. 2005) provided the distribution range for $\mathrm{H}$. thomassi as South Canara and Cardamom Hills. Later, many researchers added new records (although not supported by voucher specimens) of this species from various rivers in Kerala (see Table 1).

In the absence of recent records and contradictory claims made by researchers, the exact distribution range of $H$. thomassi remained uncertain. Abraham et al. (2011) indicated that only three species of Hypselobarbus, viz., $H$. curmuca, $H$. kolus and $H$. kurali are present in river Kallada, and suggested that the reports of $H$. thomassi from this river are not correct and is a case of misidentification (R. Abraham pers. comm. cited in Devi \& Ali 2011). Hence, based on the assumption that $H$. thomassi, is restricted to an area of $<10 \mathrm{~km}^{2}$ as two fragmented locations in the Nethravati and Kabini rivers, this species was listed as 'Critically Endangered/ $\mathrm{CR}^{\prime}$ in the IUCN Red List of Threatened Species (see Devi \& Ali 2011). A recommendation for carrying out urgent surveys in the known areas of occurrence as well as validation of the identity of the southern Kerala populations was also made (Devi \& Ali 2011).

Recently, Knight et al. (2013a) cleared the taxonomic

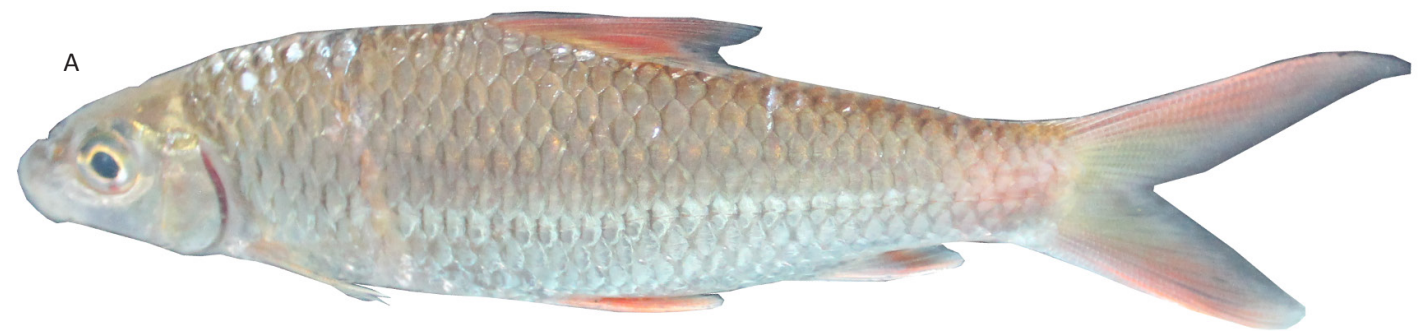

CRG-SAC.2013.45 - Vettilapara, Chalakudy, Kerala C Rajeev Raghavan

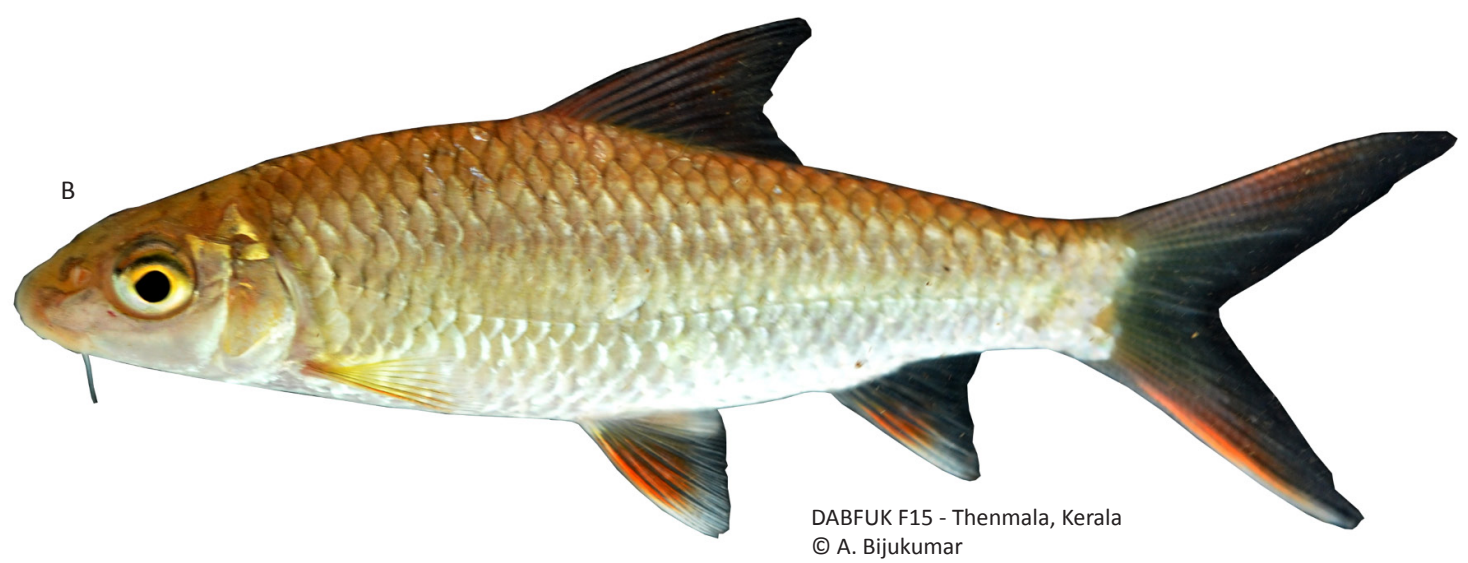

Image 1. Live specimens of Hypselobarbus thomassi from two sites in the Kerala region of Western Ghats. 


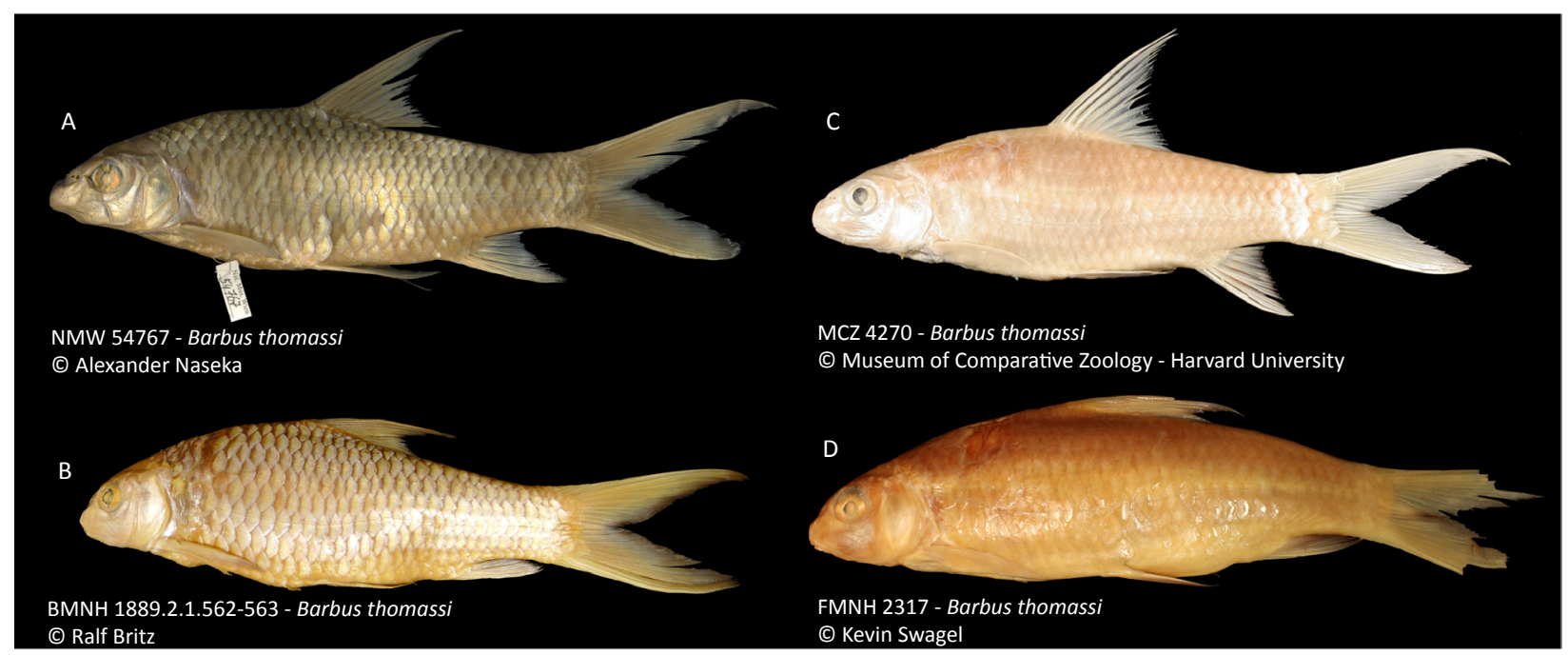

Image 2. Syntypes and/or Day's specimens of Hypselobarbus thomassi

Table 1. Previous records of Hypselobarbus thomassi from the Western Ghats

\begin{tabular}{|l|l|}
\hline Location/River & Reference \\
\hline South Canara ${ }^{1}$ & Day (1874, 1878, 1889) \\
\hline Cardamom Hills & Jayaram et al. (1976) \\
\hline Kabini River (Wayanad) & Easa \& Shaji (2003) \\
\hline $\begin{array}{l}\text { Periyar River (Malayatoor, } \\
\text { Pooyamkutty) }\end{array}$ & Thomas (2004) \\
\hline Periyar River & $\begin{array}{l}\text { Thomas et al. (2002); Beevi \& } \\
\text { Ramachandran (2009) }\end{array}$ \\
\hline Chalakudy River & $\begin{array}{l}\text { Kurup et al. (2004); Beevi \& } \\
\text { Ramachandran (2009) }\end{array}$ \\
\hline Kallada River (Kulathupuzha) & Kurup et al. (2004) \\
\hline $\begin{array}{l}\text { Tunga River (Sringeri and } \\
\text { Hariharapura) }\end{array}$ & $\begin{array}{l}\text { Ahmad \& Venkateshwarlu (2012); } \\
\text { Ahmad et al. (2013) }\end{array}$ \\
\hline Kempu Hole River & Knight et al. (2013a) \\
\hline Mula-Mutha River & Wagh \& Ghate (2003) \\
\hline
\end{tabular}

${ }^{1}$ Currently Dakshin Kannada and Udupi District of Karnataka and Kasargod District of Kerala

ambiguity surrounding the identity of $H$. thomassi after making fresh collections from its type locality. They also examined a single specimen of the species from the Athirapilly waterfalls in Chalakudy River, Kerala, and suggested that they are conspecific with the populations found in South Canara, its type locality; and that the claims made by Devi \& Ali (2011) on the taxonomic distinctiveness of the Kerala population needs to be substantiated.

Based on specimens collected from the Chalakudy, Periyar and Kallada rivers as well as re-examining materials that formed the basis of the study of Abraham et al. (2010), we provide additional information on the current distribution range of $H$. thomassi in the
Western Ghats freshwater ecoregion. Based on the updated information on distribution and threats, we then propose an updated Red List assessment for this endemic species.

\section{MATERIALS AND METHODS}

\section{Materials examined}

Hypselobarbus thomassi, CRG-SAC.2013.41, 13.vi.2013, 1 ex., $106.4 \mathrm{~mm} \mathrm{SL}$, Vettilapara, $10.287^{\circ} \mathrm{N} \&$ $76.498^{\circ} \mathrm{E}$, Chalakudy River, Kerala, India, coll. R. Raghavan \& A. Ali; Hypselobarbus thomassi, CRG-SAC.2013.72, 05.iv.2013, 1 ex., $138.31 \mathrm{~mm} \mathrm{SL}$, Rosemalai, $8.910^{\circ} \mathrm{N} \&$ $77.164^{\circ} \mathrm{E}$, Kallada river, Kerala, India, coll. Renjith Kumar; Hypselobarbus thomassi, DABFUK F 15, 20.vi.2010, 1 ex., $83 \mathrm{~mm}$ SL, Thenmala, $8.874^{\circ} \mathrm{N} \& 77.195^{\circ} \mathrm{E}$, Kallada River, Kerala, India, coll. A. Bijukumar; Hypselobarbus thomassi, CRG-SAC.2004.201, 04.iii.2004, 1 ex., 127.07mm SL, Pooyamkutty, $10.169^{\circ} \mathrm{N} \& 76.793^{\circ} \mathrm{E}$, Periyar River, Kerala, India, coll. R. Raghavan et al.

\section{Photographs and X-ray}

Barbus thomassi, F. Day, MCZ 4270, 1 ex, South Canara, India; Barbus thomassi, F. Day, FMNH 2317, 1 ex, South Canara, India; Barbus thomassi, F. Day, NMW 54767, 1 ex, South Canara, India (also radiograph - see Image 3); Barbus thomassi, F. Day, BMNH 1889.2.1.562, 1 ex, South Canara, India.

\section{Museum abbreviations}

BMNH: Natural History Museum, London; CRG-SAC: Conservation Research Group, St. Albert's College, Kochi; 


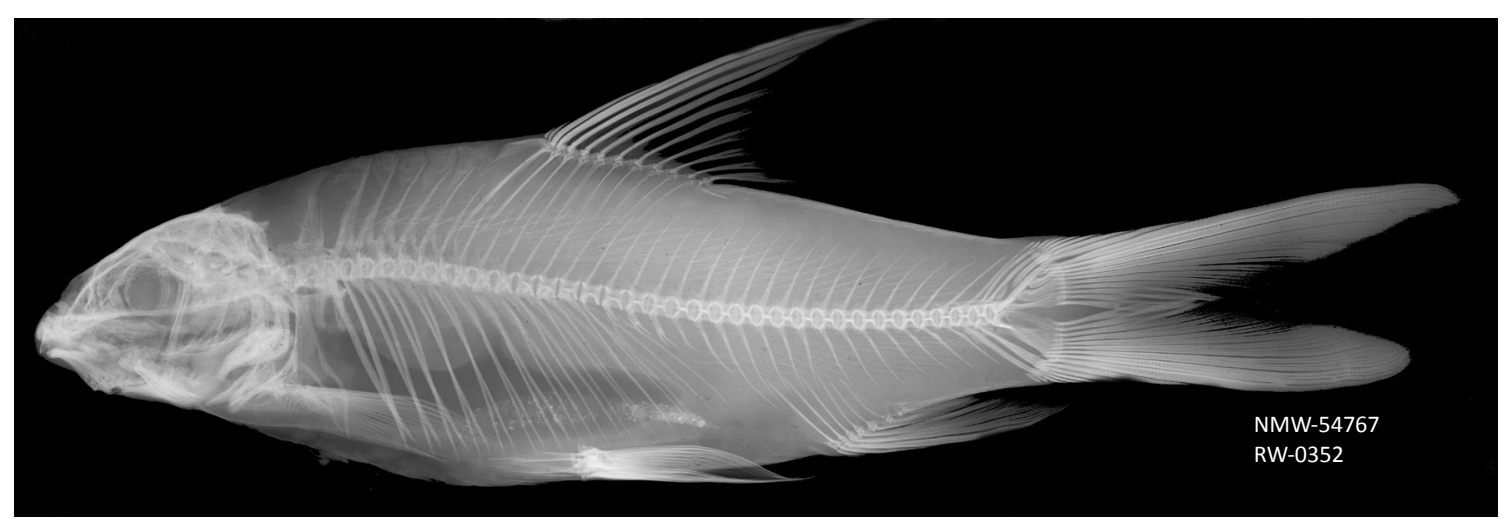

Image 3. Radiograph of a syntype of Hypselobarbus thomassi [Courtesy: Alexander Naseka]

DABFUK: Department of Aquatic Biology and Fisheries University of Kerala, Trivandrum; FMNH: Field Museum, Chicago; MCZ: Museum of Comparative Zoology, Harvard; NMW: Natural History Museum, Vienna.

\section{Taxonomy}

We use the generic name Hypselobarbus instead of Gonoproktopterus following Arunachalam et al. (2012), Yang et al. (2012), and Knight et al. (2013a,b,c).

\section{Morphometric data collection}

Counts and measurements follow Pethiyagoda et al. (2012) and Knight et al. (2013a). Measurements were taken using a digital calliper to the nearest $0.1 \mathrm{~mm}$. Subunits of body are presented as percent of standard length (SL) and subunits of head are provided as percent of head length (HL) (see Table 2).

\section{DNA isolation and molecular phylogeny}

Muscle tissue was harvested from a fresh specimen each collected from two different river systems, Chalakudy and Kallada in Kerala (CRG-SAC.2013.42, CRGSAC.2013.72.1) and was preserved in absolute ethanol. The tissue was digested at $60^{\circ} \mathrm{C}$ for two hours using the STE buffer $(0.1 \mathrm{M} \mathrm{NaCl}, 0.05 \mathrm{M}$ Tris- $\mathrm{HCl}, 0.01 \mathrm{M}$ EDTA, $1 \% \mathrm{SDS})$ with $15 \mu \mathrm{l}$ Proteinase $\mathrm{K}(20 \mathrm{mg} / \mathrm{ml})$ per $500 \mathrm{ml}$ of STE buffer. DNA was extracted using conventional phenol-chloroform method and re-suspended in nuclease free water. Polymerase chain reaction was performed to amplify mitochondrial cytochrome oxidase subunit I (cox1) gene, using the forward primer Fish R1 (5'- TCAACCAACCACAAAGACATTGGCAC-3') and reverse primer Fish R1 (5'- TAGACTTCTGGGTGGCCAAAGAATCA $-3^{\prime}$ ) (Ward et al. 2005). PCR reaction was performed in a $25 \mu \mathrm{l}$ reaction volume containing $5 \mu \mathrm{l}$ of template DNA ( 200ng), $2.5 \mu$ l of $10 \mathrm{X}$ reaction buffer (100 mM Tris $\mathrm{pH}$
9.0, $500 \mathrm{mM} \mathrm{KCl}, 15 \mathrm{mM} \mathrm{MgCl} 2,0.1 \%$ Gelatin), $2 \mu \mathrm{l}$ of $25 \mathrm{mM} \mathrm{MgCl} 2,1 \mu \mathrm{l}$ of $10 \mathrm{mM}$ dNTPs, $1 \mu \mathrm{l}$ of each primer, $1 \mu \mathrm{l}$ Taq polymerase $(1 \mathrm{U} / \mu \mathrm{l})$ and $12.5 \mu \mathrm{l}$ nuclease free water. The thermal profile was 10 mins at $95^{\circ} \mathrm{C}$, and 35 cycles of $1 \mathrm{~min}$ at $94^{\circ} \mathrm{C}, 1 \mathrm{~min}$ at $54^{\circ} \mathrm{C}$ and $2 \mathrm{mins}$ at $72^{\circ} \mathrm{C}$, followed by extension of 10 mins at $72^{\circ} \mathrm{C}$. Amplified DNA fragments were purified using the 'Promega Wizard Gel and PCR clean up' system and sequenced. The purified PCR products were sequenced using $A B I$ prism 3730 sequencer (Applied Biosystems, USA) and Big dye terminator sequencing kit ( $A B I$ Prism, USA).

BLAST tool (Altschul et al. 1990) was used to analyze the integrity of the sequence. The sequences were submitted to NCBI GenBank (accession numbers pending). We retrieved additional sequences for other related species from NCBI GeneBank database (http:// www.ncbi.nlm.nih.gov/). GenBank accession numbers for the sequences used for the analysis are provided in Table 3 and Fig. 1. Sequences were aligned using MUSCLE (Edgar 2004). A Maximum Likelihood (ML) phylogeny was built in PHYML ver 3.0 (Guindon et al. 2010) using the dataset after finding out the best fit nucleotide substitution model using MrAIC (Nylander 2004).

\section{RESULTS AND DISCUSSION}

Values of morphometric characters of the specimens that we collected (Table 2) are within the general range as observed in the putative topotypes studied by Knight et al. (2013a). Whatever minor variations that were observed were due to the reason that closely related large growing cypriniform fishes, often tend to have an allometric growth pattern (Mina et al. 1996; Patimar \& Farzi 2011), resulting in discrepancy in morphometric 
Table 2. Morphometric characters and meristics of Hypselobarbus thomassi collected from three river systems of Kerala

\begin{tabular}{|c|c|c|c|c|}
\hline & $\begin{array}{c}\text { CRG.SAC.2013.41 } \\
\text { Vettilapara, } \\
\text { Chalakudy River }\end{array}$ & $\begin{array}{c}\text { CRG.SAC.2004.201 } \\
\text { Pooyamkutty, } \\
\text { Periyar River }\end{array}$ & $\begin{array}{c}\text { CRG.SAC. } 2013.72 \\
\text { Rosemalai, Kallada } \\
\text { River }\end{array}$ & $\begin{array}{c}\text { DABFUK F15 } \\
\text { Tenmala, Kallada } \\
\text { River }\end{array}$ \\
\hline \multicolumn{5}{|l|}{ Morphometric Character } \\
\hline Standard Length (SL) in $\mathrm{mm}$ & 106.4 & 127.1 & 138.3 & 83.1 \\
\hline \multicolumn{5}{|l|}{$\% \mathrm{SL}$} \\
\hline Head Length & 25.6 & 25.4 & 25.92 & 26.5 \\
\hline Pre dorsal length & 48.0 & 50.5 & 50.62 & 47.0 \\
\hline Pre pelvic length & 53.5 & 51.8 & 54.5 & 50.6 \\
\hline Caudal peduncle length & 21.1 & 22.1 & 21.0 & 19.8 \\
\hline Body depth & 29.1 & 31.8 & 31.4 & 28.9 \\
\hline Dorsal fin height & 35.7 & 27.5 & 27.6 & 26.1 \\
\hline Dorsal fin base & 15.1 & 15.5 & 14.4 & 15.7 \\
\hline Pectoral fin length & 17.2 & 19.9 & 21.5 & 17.2 \\
\hline Pelvic fin length & 17.8 & 19.4 & 19.8 & 16.2 \\
\hline Anal fin base & 7.6 & 7.2 & 6.8 & 6.5 \\
\hline Dorsal hypural distance & 54.3 & 55.4 & 54.3 & 57.8 \\
\hline \multicolumn{5}{|l|}{ \% Head Length $(\mathrm{HL})$} \\
\hline Snout length & 41.2 & 40.8 & 37.4 & 33.4 \\
\hline Head depth & 75.3 & 71.1 & 71.4 & 72.7 \\
\hline Eye diameter & 30.2 & 29.6 & 29.0 & 27.3 \\
\hline Maxillary barbel length & 22.0 & 24.8 & 23.8 & 22.2 \\
\hline Rostral barbel length & 13.6 & 14.9 & 15.6 & 15.9 \\
\hline Internarial width & 19.9 & 20.3 & 19.5 & 22.7 \\
\hline Interorbital width & 36.0 & 35.9 & 33.7 & 34.1 \\
\hline \multicolumn{5}{|l|}{ Meristics } \\
\hline Dorsal & iv 9 & iv 9 & iv 9 & iv 9 \\
\hline Pectoral & i 15 & i 15 & i 15 & i 15 \\
\hline Ventral & i 9 & i 9 & i 9 & i 9 \\
\hline Anal & iii 5 & iii 5 & iii 5 & lii 5 \\
\hline Caudal & $1+9+8+1$ & $1+9+8+1$ & $1+9+8+1$ & $1+9+8+1$ \\
\hline Lateral line scales & $34+1$ & $33+1$ & $33+1$ & $33+1$ \\
\hline Lateral transverse Scales & $1 / 2-5-1-3$ & $1 / 2-5-1-3$ & $1 / 2-6-1-3$ & $1 / 2-6-1-3$ \\
\hline Pre Dorsal Scales & 11 & 11 & 11 & 11 \\
\hline
\end{tabular}

proportions (also see Ali et al. 2013).

\section{Description}

Body elongate, laterally compressed, dorsal profile convex with the pre dorsal contour ascending up to dorsal fin origin then descending gently towards caudal peduncle. Ventral profile also convex anteriorly up to pelvic fin origin, almost flat up to anal fin base, then slanting sharply to the caudal base.

Head laterally compressed, eyes positioned somewhat superiorly, visible from dorsal and ventral aspects. Nares placed very close to the antero-superior rim of the orbit. An elevated flap is present at the middle of the nares. Mouth sub-terminal, reaching to vertical at middle of nostrils, $U$ shaped in ventral aspect with interrupted labial fold. Two pairs of thin barbels; the rostral pair shorter than the maxillary one. Rostral barbels, when adpressed reach the base of maxillary barbels and a point in vertical from the posterior extremity of the nostrils.

Dorsal fin origin above $10^{\text {th }}$ scale of the lateral line and is slightly in advance of pelvic fin origin; sharply 
Table 3. Details of cox1 sequences of Hypselobarbus species used for the phylogenetic analyses presented in Fig 1.

\begin{tabular}{|c|c|c|c|}
\hline $\begin{array}{l}\text { Genbank Accession } \\
\text { Number }\end{array}$ & Species & Location & Remarks \\
\hline HM010710 & Hypselobarbus jerdoni ${ }^{1}$ & No location information & \\
\hline HM010712 & 'Hypselobarbus lithopidos' & India; Shimoga Fish Farm & Misidentification $^{2}$ \\
\hline KF955537 & Hypselobarbus lithopidos & India; Chandragiri & Topotype \\
\hline F9555538 & Hypselobarbus lithopidos & India; Chandragiri & Topotype \\
\hline KF955536 & Hypselobarbus thomassi & India; Vettilapara; Chalakudy & \\
\hline KF955539 & Hypselobarbus thomassi & India; Rosemalai, Kallada & \\
\hline HM010715 & 'Hypselobarbus lithopidos' & $\begin{array}{l}\text { India; Rusewalai (= Rosemalai } \\
\text { ?) fish farm }\end{array}$ & Misidentification $^{2}$ \\
\hline KC445465 & Hypselobarbus periyarensis & No location information & \\
\hline KF113559 & Hypselobarbus periyarensis & India; Periyar Tiger Reserve & Topotype \\
\hline HM010717 & Hypselobarbus periyarensis & No location information & \\
\hline HM010708 & Hypselobarbus cf. curmuca ${ }^{3}$ & No location information & \\
\hline HM010709 & Hypselobarbus dubius & No location information & \\
\hline HM010718 & Hypselobarbus micropogon & No location information & \\
\hline KC445464 & Hypselobarbus micropogon & No location information & \\
\hline HM010711 & Hypselobarbus cf curmuca ${ }^{4}$ & No location information & \\
\hline HM010716 & Hypselobarbus canarensis ${ }^{5}$ & No location information & \\
\hline HM010719 & Hypselobarbus canarensis ${ }^{5}$ & No location information & \\
\hline KC445463 & Hypselobarbus canarensis ${ }^{5}$ & No location information & \\
\hline
\end{tabular}

${ }^{1}$ as Puntius jerdoni in Genbank; ${ }^{2}$ Please see discussion in this paper and also Ali et al. (2013) and Knight et al. (2013); ${ }^{3}$ Knight et al. (2013c) cleared the taxonomic identity and established a neotype for $\mathrm{H}$. curmuca. Since the sequence HM010708 has no information on the location of collection of the specimen, we tentatively treat it as Hypselobarbus cf. curmuca; ${ }^{4}$ Genbank records state that HM010711 represent a sequence for $\mathrm{H}$. kolus. However, Knight et al. (2013c) has considered $\mathrm{H}$. kolus as a synonym of $\mathrm{H}$. curmuca. Therefore we tentatively treat the sequence as belonging to Hypselobarbus cf. curmuca; ${ }^{5} \mathrm{Genbank}$ records state that HM010716, HM010719 and KC445463 represent sequences for H. kurali. However, Knight et al. (2013c) synonymised H. kurali with H. canarensis.

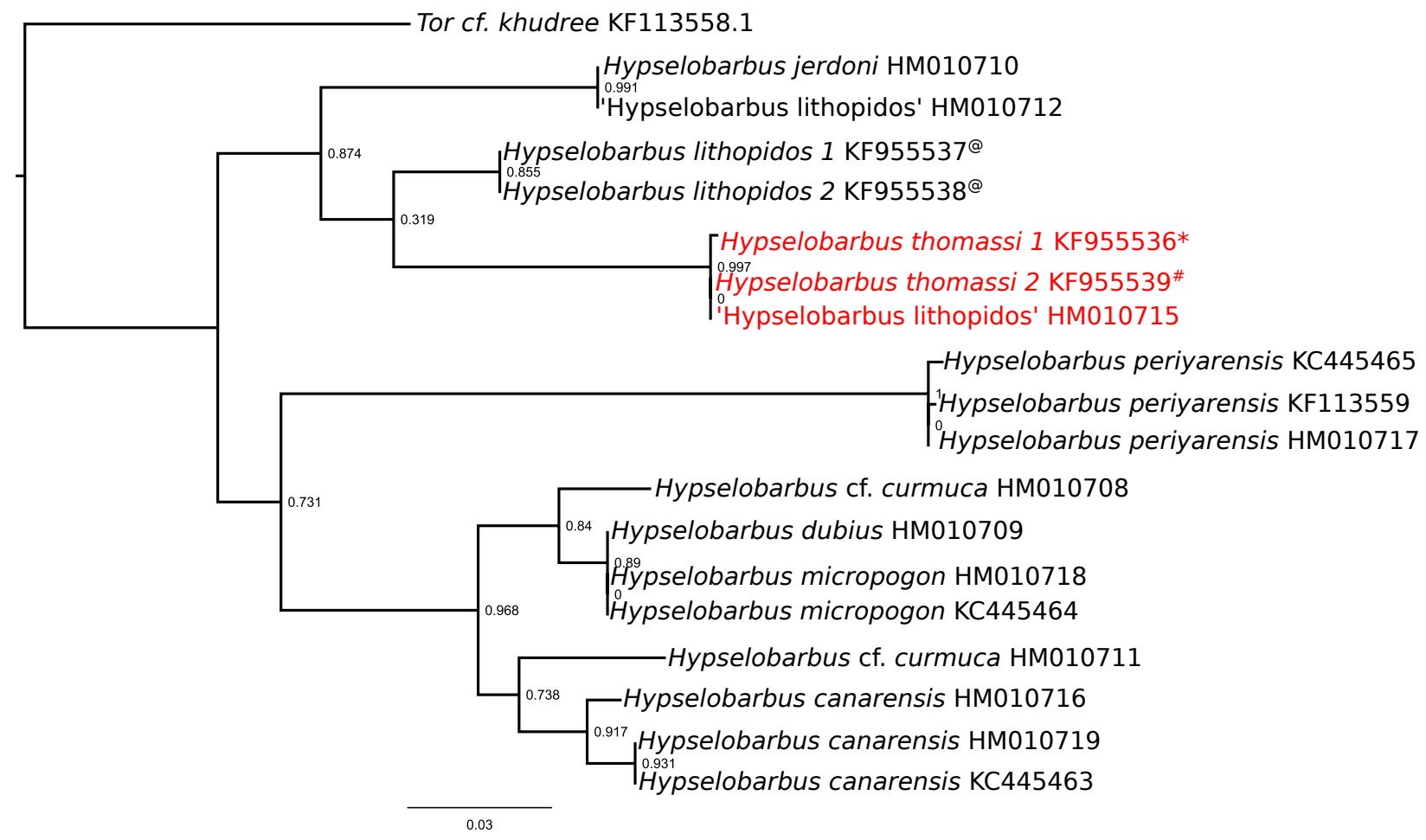

Figure 1. Maximum Likelihood tree using cox1 gene showing the phylogenetic position of Hypselobarbus thomassi in relation to its congeners. @\#* Sequenced for the present study, * Chalakkudy River, ” Kallada River; the sequences within inverted commas (" ') are misidentifications in Arunchalam et al. (2012). 
pointed at apex with a concave distal margin. Posterior margins of pectoral and pelvic fins convex, curved not reaching to vertical from insertion of pelvic fin and anal fin respectively. Anal fin with a concave distal margin; caudal fin deeply forked; both the lobes with pointed tips, upper lobe slightly longer than the lower one.

Dorsal fin with four simple and nine branched rays, the last one branched to the base. Last unbranched dorsal fin ray longest followed by the first branched ray. Pectoral fin with one simple and 15 branched rays. Pelvic fin with one simple and nine branched rays. Anal fin with three simple and five branched rays, last one branched to the base. Caudal fin with 9+8 branched rays and 3-4 procumbent rays above and below the principal fin rays of each lobe.

Lateral line complete with 33-34 pored scales, plus one unperforated scale at the base of the caudal fin. Eleven predorsal scales (excluding the notched one at fin origin) and 14 circumpeduncular scales (1/2-3-1-2-1/2 scale in transverse line). Transverse scale count between dorsal fin origin and pelvic fin origin $1 / 2+5+1+3$ and $31 / 2$ scales between lateral line and anal fin. There exist 21 pre ventral scales and 30 pre anal scales. Dorsal base sheathed with 9-10 scales where as the anal fin with 5-6 scales. One scale row between the urogenital opening and anal fin origin. The two axillary scales present at the pelvic fin base exceed a bit beyond the posterior insertion of the fin.

\section{Colouration}

Dorsal side of the body and the flanks above the lateral line are greenish grey in colour and the flanks below lateral line and the ventral side are bright silvery in colouration. Body devoid of any distinct markings. All the fins orange-red in colour at their proximal ends and with a greyish tinge at the distal ends. Head, scales and rostral barbels with many minute scattered chromatophores but is absent on the maxillary barbels (when viewed under microscope).

\section{Squamation}

Observations from the present study as well as those carried out earlier on the genus Hypselobarbus have revealed that these large barbs have a wide range in their lateral line scale counts (for e.g., 31-36 in H. thomassi; 37-39 in H. lithopidos) (Day 1874; Ali et al. 2013; Knight et al. 2013a).

\section{Distribution}

Hypselobarbus thomassi is endemic to the Western Ghats of India (Dahanukar \& Raghavan 2013). It is currently known as fragmented populations from several small west flowing rivers in the Western Ghats freshwater ecoregion, viz., Kempuhole (Karnataka State) (Knight et al. 2013a), Chalakudy, Periyar and Kallada (Kerala State) (Image 4). There are at least 26 west flowing and two east flowing river systems between Kempuhole and Chalakudy, and six west flowing and one east flowing river systems between Periyar and Kallada (see River Research Center 2013 for a list of rivers in Kerala). However, comprehensive ichthyological surveys carried out during the last decade and a half (Kurup et al. 2004; River Research Center 2013 and references therein) have failed to record $H$. thomassi from any of these rivers. Although local knowledge of fishers in Chandragiri River reveal that the species is sometimes caught, there are no voucher specimens to confirm this. Nevertheless, the location of the Chandragiri basin in the larger South Canara landscape (the type locality of the species) may actually mean that the species could be present in the river. The records of $H$. thomassi from two east flowing river systems, Kabini River of Cauvery River system (Easa \& Shaji 2003), and Tunga-Bhadra (Ahmad \& Venkateshwarlu 2012; Ahmad et al. 2013) and Mula-Mutha Rivers of Krishna River system (Wagh \& Ghate 2003), are difficult to verify as there are no voucher specimens. It is also essential to note that the record of this species from Mula-Mutha River by Wagh \& Ghate (2003), based on the collections made during 1992-1995, is likely to be wrong because the species was neither recorded during previous (Fraser 1942; Suter 1944; Tonapi \& Mulherkar 1963), nor later (Kharat et al. 2001) studies.

Until reliable records backed up by voucher specimens are available from the east flowing rivers (Cauvery and Krishna), we considerer $\mathrm{H}$. thomassi to be restricted to the west flowing rivers of the Western Ghats. We therefore exclude the records of the species from east flowing drainages in the distribution map (Image 4).

\section{Population status}

Currently there is very little information on the population status of $\mathrm{H}$. thomassi from its native range. Menon (2004) mentioned that an extensive search in South Canara, the type locality $H$. thomassi, resulted in the collection of only one specimen. Local knowledge of fishers in the Chalakudy and Periyar rivers reveal that the fish is not common and is rarely caught. Extensive surveys in the Kasargod District of Kerala State (erstwhile South Canara - type locality) including Chandragiri (Biju 2005) as well as neighbouring basins of Uppala and 


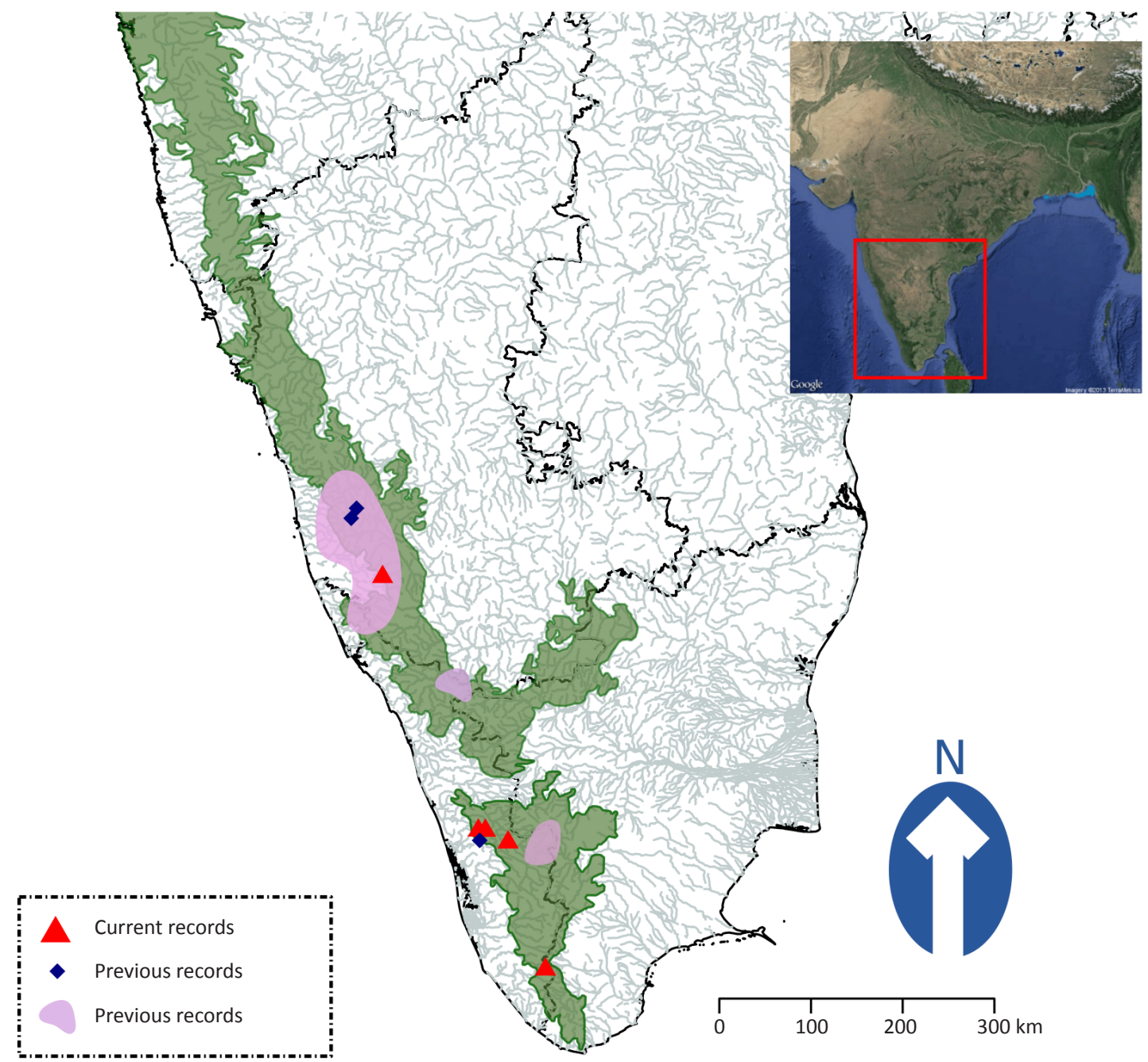

Image. 4. Map showing the distribution range of Hypselobarbus thomassi in the Western Ghats region [the pink shades denote occurrence records of the species where information on the exact location is unavailable]

Manjeshwaram (Biju et al. 1999 a,b) did not yield any specimens of $H$. thomassi. Although, Ramachandra et al. (2012) suggested that $H$. thomassi is extirpated from several west flowing rivers of Karnataka including Kali, Bedti, Aghanashini, Sharavati and Nethravati, Knight et al. (2013a) collected several specimens from Nethravati indicating that the fish is still extant.

\section{Habitat and Ecology}

Hypselobarbus thomassi inhabits pool-riffle, run and glide habitats in fast to moderately flowing streams shaded with a fine amount of riparian vegetation. It favours clear, well oxygenated water flowing gently over substrates that are extensively encountered in these microhabitats such as boulders, bedrocks and sand. The adults of the species always dwell in moderately deep pools, whilst the juveniles are seen in the shallow areas associated with the pool-riffle and run habitats. The habitats of $H$. thomassi in the three river systems of Kerala are shown in Images 5-7.

\section{Phylogenetic position}

A genetic distance of $0.1 \%$ was observed between the cox1 sequence of $H$. thomassi, from the Chalakkudy River and Kallada River. Interestingly, the sequence generated from the specimen collected from Kallada River (Fig. 1) demonstrates the uniqueness with a sequence from the GenBank (HM010715) which was deposited as $\mathrm{H}$. lithopidos (from Rosemalai - also in the Kallada River system) (see Arunachalam et al. 2012). These three sequences formed a monophyletic group (Fig. 1) which was sister to the topotypic sequences of $H$. lithopidos collected for the present study. The average genetic distance between the sequence of topotypic 


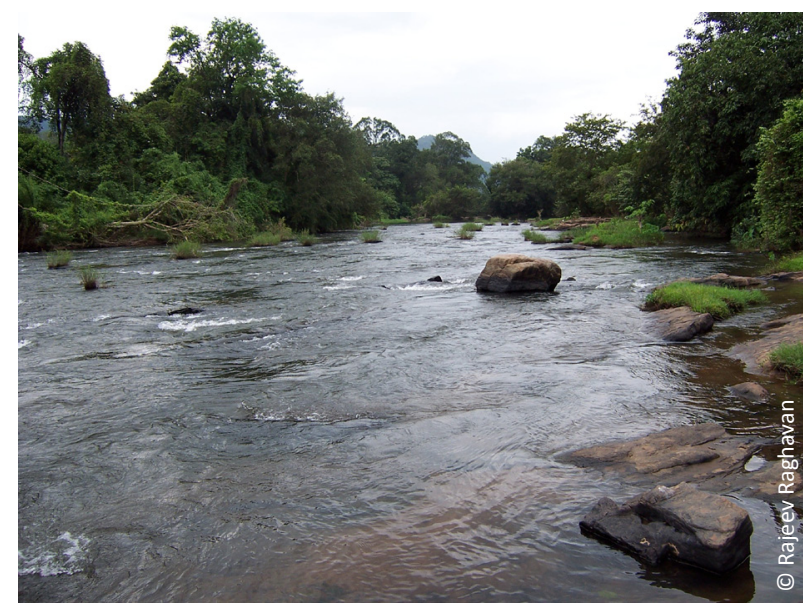

Image 5. Habitat of Hypselobarbus thomassi at Vettilapara in Chalakudy River. Image taken on 18 February 2004.

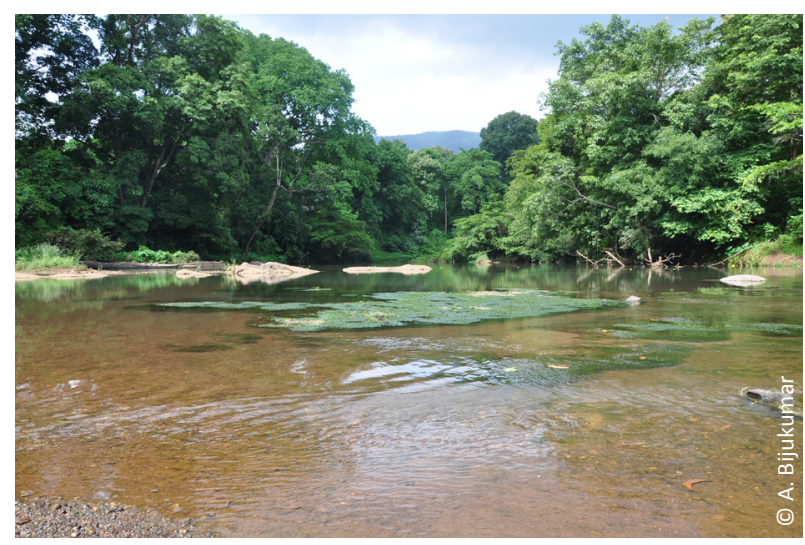

Image 7. Habitat of Hypselobarbus thomassi at Thenmala in Kallada River. Image taken on 04 March 2004.

H. lithopidos, collected from South Canara, and the $H$. thomassi sequences were $4.85 \%$. This confirms that the sequence HM010715, collected from Rosemalai, is in fact $H$. thomassi and not $H$. lithopidos as argued by Arunachalam et al. (2012). Our phylogenetic analysis and additional observations made in two recent papers (Ali et al. 2013; Knight et al. 2013a) demonstrates that Arunachalam et al. (2012) provides an inaccurate picture of the phylogenetic relationship of the genus Hypselobarbus.

\section{Threats and conservation}

To the best of our knowledge, there is no targeted fishery of $\mathrm{H}$. thomassi as a food fish anywhere in its distribution range. However, they are caught along with other species of Hypselobarbus as well as Mahseer (Tor sp.) in the Kallada River in Kerala. Unmanaged aquarium trade (see Raghavan et al. 2013) is a concern as local

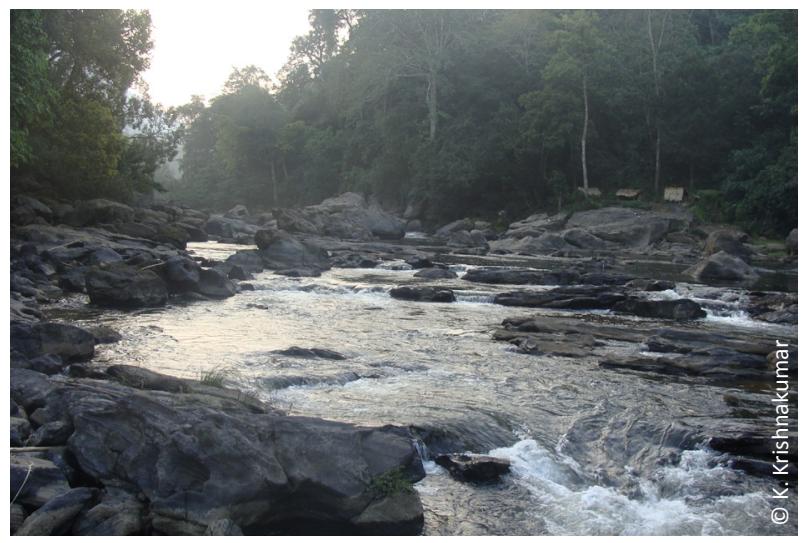

Image 6. Habitat of Hypselobarbus thomassi at Pooyamkutty in Periyar River. Image taken on 09 January 2008.

fishers acknowledge the fact that juvenile $H$. thomassi are sometimes caught as by-catch during aquarium fish collections for its congener, $H$. jerdoni in the rivers of Dakshin Kannada and Kasargod districts of Kerala (=erstwhile South Canara). Destructive fishing practices especially dynamiting is a major threat to the species in the streams around Pooyamkutty in Periyar River, as well as in Umayar, Rosemalai and Katalapara regions of Kallada river. Poisoning and electric fishing are prevalent in the Sullia region of Dakshin Kannada, especially when the water levels are low (see Ali et al. 2013).

Currently, H. thomassi has been listed as 'Critically Endangered' (Devi \& Ali 2011) in the IUCN Red List of Threatened Species based on limited distribution information available during the assessment. Additional information on distribution, threats and taxonomic clarifications (Knight et al. 2013a; this paper) have led to a scenario where the conservation status of the species needs to be re-assessed. The proposed Red List Status of the species has been provided in Appendix 1.

\section{CONCLUSIONS}

In spite of research that began more than two hundred years ago, our knowledge on the diversity and distribution of freshwater fishes of Western Ghats is far from complete. Studies such as those reported in the present paper, as well as others (for e.g., Katwate et al. 2012; Ali et al. 2013; Emmanuel et al. 2013; Knight et al. 2013a,b,c;) are addressing this gap in knowledge on species distribution, widely termed as the 'Wallacean shortfall' thereby facilitating the development and implementation of conservation policies and action in this exceptional region of freshwater biodiversity. 


\section{REFERENCES}

Abraham, R.K., N. Kelkar \& A.B. Kumar (2011). Freshwater fish fauna of the Ashambu Hills landscape, southern Western Ghats, India, with notes on some range extensions. Journal of Threatened Taxa 3(3): 1585-1593; http://dx.doi.org/10.11609/JoTT.o2528.1585-93

Ahmad, S., M. Muralidharan, M. Venkateshwarlu \& M. Arunachalam (2011). Distribution pattern, endemism, threat status and conservation measures of fishes in the Tunga and Bhadra rivers of Western Ghats, India. Environmental Biology of Fishes 96(10-11): 1245-1256; http://dx.doi.org/10.1007/s10641-011-9915-y

Ahmad, S. \& M. Venkateshwarlu (2012). Habitat Ecology of Cyprinid Fish Community in Relation to Environmental Factors of Tunga and Bhadra Rivers, Western Ghats, Karnataka (India). Journal of Research \& Development 12: 65-91.

Ali, A., S. Philip \& R. Raghavan (2013). Back from obscurity: notes on the current distribution, threats and conservation status of a poorly known cyprinid, Hypselobarbus lithopidos (Day, 1874) from the Western Ghats of India. Journal of Threatened Taxa 5(13): 47434751; http://dx.doi.org/10.11609/JoTT.o3655.4743-51

Arunachalam, M., M. Raja, M. Muralidharan \& R.L. Mayden (2012). Phylogenetic relationships of species of Hypselobarbus (Cypriniformes: Cyprinidae): an enigmatic clade endemic to aquatic systems of India. Zootaxa 3499: 63-73.

Beevi, K.S.J. \& A. Ramachandran (2009). Checklist of freshwater fishes collected from Ernakulam District, Kerala, India. Journal of Threatened Taxa 1(9): 493-494; http://dx.doi.org/10.11609/JoTT. 01559.493-4

Biju, C.R. (2005). Habitat and Distribution of Hillstream Fishes of Northern Kerala (north of Palghat Gap). PhD Thesis. Mahatma Gandhi University, Kottayam, India.

Biju, C.R., K.R. Thomas \& C. Ajithkumar (1999a). Freshwater fish distribution in the Manjeshwaram River, Kasargod District, Kerala, India. Journal of the Bombay Natural History Society 96(1): 159-161.

Biju, C.R., K.R. Thomas \& C. Ajithkumar (1999b). Distribution of freshwater fishes in the Uppala River, Kasargod District, Kerala. Journal of the Bombay Natural History Society 96(2): 334-335.

Dahanukar, N. \& R. Raghavan (2013). Freshwater fishes of Western Ghats: Checklist v 1.0 August 2013. MIN - Newsletter of IUCN SSC/ WI Freshwater Fish Specialist Group - South Asia and the Freshwater Fish Conservation Network of South Asia (FFCNSA) 1: 6-16.

Day, F. (1874). On some new or little-known fishes of India. Proceedings of the Zoological Society of London 1873(3): 704-710.

Day, F. (1878). The Fishes of India; Being A Natural History of the Fishes Known to Inhabit the Seas and Fresh Waters of India, Burma, and Ceylon - Part 4. Beknard Quaritch: London, i-xx+553-579, pls. 139195.

Day, F. (1889). Fishes. In: Blanford, W.T. (ed). The Fauna of British India including Ceylon and Burma. Taylor \& Francis, London. v. 1: 1-xviii+1-548.

Devi, K.R. \& A. Ali (2011). Hypselobarbus thomassi. In: IUCN 2013. IUCN Red List of Threatened Species. Version 2013.1. <www. iucnredlist.org>. Downloaded on 24 October 2013.

Devi, K.R., T.J. Indra, M.B. Raghunathan \& M.S. Ravichandran (2005). Fish fauna of the Anamalai hill ranges, Western Ghats, India. Zoos Print Journal 20(3): 1809-1811; http://dx.doi.org/10.11609/JoTT. ZPJ.1164a.1809-11

Easa, P.S. \& C.P. Shaji (2003). Biodiversity Documentation for Kerala. Part 8. Freshwater Fishes. Kerala Forest Research Institute Handbook No 17. 127pp

Edgar, R.C. (2004). MUSCLE: multiple sequence alignment with high accuracy and high throughput. Nucleic Acids Research 32: 17921797; http://dx.doi.org/10.1093/nar/gkh340.

Emmanuel, J., K. Krishnakumar, B. Pereira, A. Kanagavel, A. Ali \& R. Raghavan (2013). New records of the Endangered balitorid loach, Travancoria elongata Pethiyagoda \& Kottelat 1994, from the Kerala part of the Western Ghats, India. Journal of Threatened Taxa 5(10): 4504-4509; http://dx.doi.org/10.11609/JoTT.o3407.4504-9
Fraser, A.G.L. (1942). Fish of Poona. Part I. Journal of the Bombay Natural History Society 43(1): 79-91.

Guindon, S., J.F Dufayard, V. Lefort, M. Anisimova, W. Hordijk \& O. Gascuel. (2010). New algorithms and methods to estimate maximum-likelihood phylogenies: assessing the performance of PhyML 3.0. Systematic Biology 59: 307-321; http://dx.doi. org/10.1093/sysbio/syq010

Jayaram, K.C. (2010). The Freshwater Fishes of The Indian Region. Revised $2^{\text {nd }}$ Edition. Narendra Publishing House, $616 \mathrm{pp}+\mathrm{xxxixpls.}$

Jayaram, K.C. (1981). The Freshwater Fishes of India, Pakistan, Bangladesh, Burma and Sri Lanka - A Handbook. Zoological Survey of India. i-xxii + 1-475, Pls. 1-13.

Jayaram, K.C., T.J. Indra \& M.S. Singh (1976). On a collection of a fish from the Cardamom Hills, south India. Madras Journal of Fisheries 7: 1-7.

John C.C. (1936). Freshwater fish and fisheries of Travancore. Journal of the Bombay Natural History Society 38(4): 702-733.

Katwate, U., R. Raut., M. Khot., M. Paingankar \& N. Dahanukar (2012). Molecular Identification and Ecology of a Newly Discovered Population of Sun Catfish Horabagrus brachysoma from NorthernWestern Ghats of India. ISRN Zoology, 2012: 1-9. http:// dx.doi.org/10.5402/2012/419320

Kharat, S.S., N. Dahanukar \& R. Raut (2001). Decline of fresh-water fish of Pune urban area. Journal of Ecological Society 13/14: 46-51.

Knight, J.D.M., A. Rai \& R.K.P. D'souza (2013a). Re-description of Hypselobarbus lithopidos (Teleostei: Cyprinidae), based on its rediscovery from the Western Ghats, India, with notes on $H$. thomassi. Journal of Threatened Taxa 5(13): 4734-4742; http:// dx.doi.org/10.11609/JoTT.03602.4734-4742

Knight, J.D.M., A. Rai \& R.K.P. D'souza (2013b). Rediscovery of Hypselobarbus pulchellus, an endemic and threatened barb (Teleostei: Cyprinidae) of the Western Ghats, with notes on $H$. dobsoni and H. jerdoni. Journal of Threatened Taxa 5(17): 51945201; http://dx.doi.org/10.11609/JoTT.03686.5194-201

Knight, J.D.M., A. Rai \& R.K.P. D’souza (2013c). On the identities of Barbus mussullah Sykes and Cyprinus curmuca Hamilton with notes on the status of Gobio canarensis Jerdon (Teleostei: Cyprinidae). Zootaxa 3750(3): 201-215.

Kurup, B.M., K.V. Radhakrishnan \& T.G. Manojkumar (2004) Biodiversity Status of Fishes Inhabiting Rivers of Kerala (South India) With Special Reference to Endemism, Threats and Conservation Measures. In: Welcomme, R.L \& T. Petr. (eds), Proceedings of the Second International Symposium on the Management of Large Rivers for Fisheries 2 (LARS2), Cambodia, 310pp.

Menon, A.G.K. (2004). Threatened fishes of India and their conservation. Zoological Survey of India. Kolkatta, India, 170pp.

Menon, A.G.K. (1999). Check list - fresh water fishes of India. Records of the Zoological Survey of India. Miscellaneous Publication, Occasional Paper No. 175: i-xxviii+1-366pp.

Mina, M.V., A.N. Mironovsky \& Y. Dgebuadze (1996). Lake Tana large barbs: phenetics, growth and diversification. Journal of Fish Biology 48(3): 383-404; http://dx.doi.org/10.1111/j.1095-8649.1996. tb01435.x

Nylander, J.A.A. (2004). MrAIC.pl. Program distributed by the author. Evolutionary Biology Centre, Uppsala University.

Patimar, R. \& S. Farzi (2011). Life history and other biological traits of the trout barb Capoeta trutta in the River Meymeh (western Iran). Folia Zoologica 60(2): 153-158.

Pethiyagoda, R., M. Meegaskumbura \& K. Maduwage. (2012). A synopsis of the South Asian fishes referred to Puntius (Pisces: Cyprinidae). Ichthyological Exploration of Freshwaters 23(1): 69-95.

Pillai, R.S.N. (1929). A list of fishes taken in Travancore from 19011915. Journal of the Bombay Natural History Society 33(2): 347-379.

Raghavan, R., N. Dahanukar, M. Tlusty, A. Rhyne, K. Krishnakumar, S. Molur \& A.M. Rosser (2013). Uncovering an obscure trade: threatened freshwater fishes and the aquarium pet markets. Biological Conservation 164: 158-169; http://dx.doi.org/10.1016/j. biocon.2013.04.019

Ramachandra, T.V., M.D. Subash Chandran, N.V. Joshi, Sreekantha, 
R. Kumar, R. Rajinikanth, S.R. Desai \& S. Babu (2012). Ecological Profile of Sharavathi River Basin., Sahyadri Conservation Series 22, ENVIS Technical Report : 52, November 2012, Energy \& Wetlands Research Group, Centre for Ecological Sciences, Indian Institute of Science, Bangalore, India.

River Research Centre (2013). Report on Monitoring of Fish Diversity of Rivers in Kerala. Kerala State Biodiversity Board (KSBB), Thiruvananthapuram, 98pp.

Silas, E.G. (1951). On a collection of fish form the Annamalai and Nelliampathi Hill ranges (Western Ghats) with notes on its zoogeographical significances. Journal of the Bombay Natural History Society 49: 670-681.

Suter, M. (1944). New records of fish from Poona. Journal of Bombay Natural History Society 44(3): 408-414.

Talwar, P.K. \& A.G. Jhingran (1991). Inland Fishes of India and Adjacent Countries - 2 Volumes. Oxford \& IBH Publishing Co. New Delhi, 1158pp.

Thomas, R. (2004). Habitat and distribution of hill stream fishes of southern Kerala. PhD Thesis, Mahathma Gandhi University, Kottayam, Kerala, India.

Thomas, R.K., M.J. George \& C.R. Biju (2002). Freshwater fishes of southern Kerala with notes on the distribution of endemic and endangered species. Journal of the Bombay Natural History Society 99(1): 47-53.

Tonapi, G.T. \& L. Mulherkar (1963). Notes on the freshwater fauna of Poona, Part: 1 - Fishes. Proceedings of the Indian Academy of Sciences 58: 187-197; http://dx.doi.org/10.1007/BF03051937

Wagh, G.K. \& H.V. Ghate (2003). Freshwater fish fauna of the rivers Mula and Mutha, Pune, Maharashtra. Zoos' Print Journal 18(1): 977-981; http://dx.doi.org/10.11609/JoTT.ZPJ.18.1.977-89

Ward, R.D., T.S. Zemlak, B.H. Innes, P.R. Last \& P.D. Hebert (2005). DNA barcoding Australia's fish species. Philosophical Transactions of the Royal Society B: Biological Sciences 360(1462): 1847-1857; http://dx.doi.org/10.1098/rstb.2005.1716

Yang, M., V. Hirt, T. Sado, M. Arunachalam, R. Manickam, K.L. Tang, A.M. Simons, H. Wu, R. Mayden \& M. Miya (2012). Phylogenetic placements of the barbin genera Discherodontus, Chagunius, and Hypselobarbus in the subfamily Cyprininae (Teleostei: Cypriniformes) and their relationships with other barbins. Zootaxa 3586: 26-40.
Author Details: ANVAR AL is interested in taxonomy and systematics of freshwater fishes of the Western Ghats. SIBY PHILIP is interested in molecular phylogenetics, evolution and biogeography of freshwater fishes of the South Asia region. NEELESH DAHANUKAR works in taxonomy, ecology and evolutionary biology of fishes and amphibians with emphasis on mathematical and statistical analysis. C.R. RENIITHLUMAR works on diversity, distribution and conservation of freshwater fishes of the Kerala region of Western Ghats. A. BIJUKUMAR is interested in biodiversity documentation and taxonomy, and involved in biodiversity/ environmental education activities to facilitate conservation. RAJEEV RAGHAVAN is interested in interdisciplinary research focused on generating information and developing methods to support conservation decision-making in freshwater ecosystems.

Acknowledgements: Rajeev Raghavan thanks Ralf Britz, Natural History Museum (NHM), London for his help with the examination of Day's materials, for photographs and useful discussions; Helmut Wellendorf, Natural History Museum, Vienna (NMW); Leo Smith and Kevin Swagel, Field Museum, Chicago (FMNH) for their help in providing photographs and radiographs of syntypes; Ambily Nair for her constant help and support; K. Krishnakumar, Fibin Baby and Benno Pereira for assistance and logistics in the field.; Anvar Ali, C.R. RenjithKumar, A. Bijukumar and Rajeev Raghavan thanks the local fishers in and around Chalakudy, Pooyamkutty and Thenmala for the cooperation and help during the field work. 


\section{APPENDIX 1 \\ PROPOSED RED LIST StATUS FOR HYPSELOBARBUS thOMASSI}

CURRENT StATUS: Critically Endangered B2ab(iii)

Proposed Status: Endangered B2ab(iii)

\section{Taxonomy}

SCIENTIFIC NAME: Hypselobarbus thomassi

SPECIES AUTHORITY: Day (1874)

COMmon nAmES: Red Mahseer, Red Canarese Barb, Nilgiri Shark, Kempu Peruval (Kannada), Chemban Kooral (Malayalam)

SYNONYMS: Barbus thomassi, Puntius thomassi, Gonoproktopterus thomassi

TAXONOMIC NOTES: Hypselobarbus thomassi was described by Day (1874) from the inland waters of erstwhile South Canara, India. There is considerable taxonomic ambiguity on the genus Hypselobarbus. Species currently placed within this genus have been placed in Barbus (Day 1874), Puntius (Jayaram 1981), Gonoproktopterus (Jayaram 2010; Pethiyagoda et al. 2012) and Hypselobarbus (Arunachalam et al. 2012; Yang et al. 2012; Ali et al. 2013; Knight et al. 2013a,b,c). The most recent paper (Knight et al. 2013c) has cleared the generic status of Hypselobarbus, which we follow.

\section{Assessment Information}

RED LIST CATEGORY AND CRITERIA: Endangered B2ab(iii)

JUSTIFICATION: Hypselobarbus thomassi is assessed as Endangered because of its severely fragmented and restricted distribution to four west flowing river systems of the Western Ghats, with an estimated area of occupancy (AOO) of less than $100 \mathrm{~km}^{2}$ (approximately $20 \mathrm{~km}$ stretch in each river with an average width of $250 \mathrm{~m}$ ) based on the distribution of the species in the middle reaches (60-400 $\mathrm{m}$ altitude) of the known hydrobasins. There is also a continuing decline in the quality of the habitats throughout its range due to pollution, dams and destructive fishing practices.

\section{Geographic range}

RANGE DESCRIPTION: Endemic to the Western Ghats freshwater ecoregion, where they are currently known from four west flowing river systems, Kempuhole (Karnataka State), Chalakudy, Periyar and Kallada (Kerala State) (present study; Knight et al. 2013a), and probably the Chandragiri River system (Kerala/Karnataka). The estimated (approximate) current extent of occurrence (EOO) is less than $5,000 \mathrm{~km}^{2}$ and current (approximate) area of occupancy (AOO) no more than $500 \mathrm{~km}^{2}$.

COUNTRIES: India (states of Karnataka and Kerala)

RANGE MAP: see Image 4

\section{Habitat and Ecology}

HABITAT AND ECOLOGY: Known to inhabit pool-riffle, run and glide habitats in fast to moderately flowing streams. The fish is known to attain sizes up to $100 \mathrm{~cm}$ (Menon 1999), although average sizes are in the range of $60 \mathrm{~cm}$ and $4 \mathrm{~kg}$ (see Knight et al. 2013a).

SYSTEMS: Freshwater

\section{Threats}

MAJOR THREATS: Destructive fishing practices including dynamiting and poisoning are the major threats in its distribution range. Habitat alteration through sand mining, construction of dams and other barrages, pollution and unmanaged collections (especially of juveniles) for the aquarium pet trade pose additional risks to local populations.

Population

POPULATION: No information on the population status. Local knowledge of fishers in its distribution range indicate that the fish is rare compared to its congeners.

POPULATION TREND: Decreasing

\section{Conservation}

CONSERVATION ACTION: No conservation actions are also currently in place. Except for the populations inside the Shenduruney Wildlife Sanctuary in Kerala, much of the range of this species is outside protected areas. The project on 'Lost fishes of the Western Ghats' is involved in research, education and awareness on poorly known species of the region including $H$. thomassi. Increased survey efforts are needed in other river systems of southern Karnataka and northern Kerala (in around the type locality: South Canara) to confirm whether undiscovered populations exist. Education and awareness programs need to be carried out in close cooperation with the Fisheries Department as well as local self governments (Panchayath) in its range. There is also a need to confirm the exact identity of the specimens from the east flowing drainages of Krishna and Cauvery, currently recorded as $H$. thomassi. 